\title{
Protein digestion in the stomachs and intestines of the cow
}

\author{
A. Th. van 't Klooster and H. A. Boekholt \\ Department of Animal Physiology, Agricultural University, Wageningen, the Nether- \\ lands
}

Received: 4 September 1972

\section{Summary}

1. The digestion and conversion of different nitrogen $(N)$ fractions along the gastrointestinal tract of two fistulated cows ( $\mathrm{Z}$ and $\mathrm{W}$ ) was studied. Different rations varying in $\mathrm{N}$ intake from 149 to $330 \mathrm{~g}$ per day and with lysine contents of 2.7 to $5.7 \mathrm{~g}$ per $16 \mathrm{~g}$ $\mathrm{N}$ were fed to each of the cows in four experimental periods. Fistulae were located in the rumen, proximal duodenum and distal ileum (about $0.5 \mathrm{~m}$ proximal to the caecum). Representative samples of feed, digesta and faeces were collected and analysed for organic matter, $\mathrm{N}$, ammonia and $\alpha$-amino $\mathrm{N}$; feed and digesta were also analysed for 15 different amino acids. $\mathrm{Cr}_{2} \mathrm{O}_{3}$ and poly(ethylene glycol) were used to calculate the quantities of digesta that passed the duodenum and flowed to the caecum.

2. Ammonia $\mathrm{N}$ constituted 2 to $9 \%$ of the $\mathrm{N}$ in duodenal contents and less than $2 \%$ of the $\mathrm{N}$ in feed, ileal contents and faeces. Mean values and standard deviations for the proportion of $\alpha$-amino $\mathrm{N}$ in non-ammonia $\mathrm{N}$ were in feed $67 \pm 7$, in duodenal contents $64 \pm 2$, in ileal contents $56 \pm 1$ and in faeces $57 \pm 2 \%$.

3. The quotient of amount of non-ammonia $\mathbf{N}$ in duodenal contents to amount of $\mathrm{N}$ ingested in each experimental period was for a ration of hay and concentrate (period I) 1.01 , for a semisynthetic ration adequate in $\mathrm{N}$ (period III) 1.17 , for a semisynthetic ration low in $\mathrm{N}$ (period IV) 1.37, and for a grass ration (period V) 0.91 .

4. Duodenal protein showed a more constant amino acid pattern than protein fed, due to the levelling effect of microbial synthesis. However, the low lysine content of rations fed in period III and IV were not fully compensated by the microbial action in the stomachs.

5. Disappearance from the small intestine (or net absorption) of non-ammonia $\mathbf{N}$ and $\alpha$-amino $\mathrm{N}$ in the different experiments averaged $65 \pm 4 \%$ and $70 \pm 4 \%$ of the amounts in duodenal contents, respectively. The significant difference could be ascribed to the addition of bile constituents (bile pigments) and the increasing preponderance of bacterial cell wall nitrogen constituents.

6. Net absorption of amino acids was on average $4 \%$ higher $(\mathrm{P}<0.01)$ than the net absorption of $\alpha$-amino N. Amino acids, thought to be essential (group 1 amino acids) as a group, were absorbed in greater amounts $(\mathrm{P}<0.01)$ than the unessential amino acids (group 2 amino acids).

7. The relative proportions - grammes amino acid as a percentage of total amino acids determined - of lysine, threonine, isoleucine, tyrosine and glycine in duodenal protein were significantly higher than in the protein fed. Smaller proportions were found for leucine, arginine, glutamic acid, valine and serine. At passing of the digesta 
through the small intestine increases of the proportions of glycine, threonine and serine were found; decreases were noted for leucine, tyrosine and arginine.

\section{Introduction}

Protein digestion in the ruminant can be considered to be in two parts involving first the microbial action of reticulo-rumen and second the post-ruminal digestion that occurs principally in the small intestine. In the past several years review papers have dealt with a number of different aspects of nitrogen metabolism in the ruminant (Waldo, 1968; Smith, 1969; Purser, 1970; Chalupa, 1972). In brief, the rumen bacteria split dietary and endogenous protein entering the rumen into amino acids and further into ammonia and volatile fatty acids. Part of these reaction products may subsequently be incorporated into protein by the micro-organisms while a large part of the remainder is absorbed from the rumen. The amount of protein that passes from the reticulo-rumen will be greater, equal to or less than that consumed depending on the degree of splitting and the amount of microbial synthesis from dietary and endogenous nitrogen. Synthesis of protein appears to be controlled by the availability to the micro-organisms of energy released during fermentation in the rumen (Walker, 1965; Hogan and Weston, 1970).

Not all dietary protein is degraded in the rumen. Weller et al. (1958) found that the rumen microbial nitrogen accounted for $63-82 \%$ of the dietary nitrogen. About $50 \%$ of the protein passing from the stomachs to the small intestine of sheep and calves was of microbial origin in experiments of Hogan and Weston (1970) and Smith and McAllan (1971), respectively. The amount of rumen degradation of dietary protein and the subsequent synthesis of microbial protein is dependent on such factors as the solubility of the protein fed and the ratio of protein to digestible organic matter. Ruminant protein requirement must ultimately be considered in terms of amino acid requirement for maintenance and production. This necessitates knowledge of the quantity and proportion of amino acids available for absorption from the intestine. The mixture of amino acids available for absorption is supplied by microbial protein synthesized in the rumen, undegraded food proteins which bypass the rumen and endogenous secretions. Amount and composition of the protein presented to the intestine have been studied in sheep (Clarke et al., 1966; Coelho da Silva et al., 1972) and cattle (Dirksen et al., 1972; Neudoerffer et al., 1971).

Although protein is extensively transformed in the reticulo-rumen by microbial action, amino acids are not absorbed from this site in any quantity (Blackburn, 1965). Amino acid absorption is almost fully restricted to the small intestine. Kay (1969) reviewed the protein digestion in the intestines and the conditions that may effect this.

Absorption of amino acids from the small intestine of ruminants has received limited attention. The amount of individual amino acids disappearing in the small intestine of sheep have been estimated by Clarke et al. (1966) and Coelho da Silva et al. (1972). Neudoerffer et al. (1971) studied the amino acid absorption of cattle on a low and a high maize diet.

Ammonia absorption is at least partly responsible for the disappearance of nitrogen from the large intestine (Hecker, 1971).

The objective of this study was to estimate the nature and quantity of nitrogen compounds presented to and disappearing from the small intestine of cows fed rations of varying composition. This study is part of a larger investigation designed to determine the site of digestion and absorption of organic and inorganic compounds along the gastro-intestinal tract of cows (van 't Klooster and Rogers, 1969). 


\section{Materials and methods}

Experiments were carried out with 2 cows, $Z$ and $W$, fitted with permanent fistulae in the rumen and in the proximal duodenum and distal ileum approximate to the caecum (van 't Klooster and Rogers, 1969). Milk yields of $\mathrm{Z}$ and $\mathrm{W}$ declined during the 4month trial from 12 to 9 and from 13 to $10 \mathrm{~kg}$ /day, respectively. The composition of the diets offered at levels approaching ad libitum intake is shown in Table 1 . In period II the same ration was offered as in period I, but an additional amount of potassium salts was placed into the rumen twice daily. Results of period II were omitted in the present paper. In period III and IV only $3 \mathrm{~kg}$ of hay were fed per day; 4 and $3 \mathrm{~kg}$ of cellulose (paper pulp) were mixed with the concentrate mixture and fed as a wet mash twice daily to $Z$ and $W$, respectively. Crude protein intake in period III was about $15 \%$ above the standard given by the Central Animal Feeding Office in the Netherlands. In period IV the protein intake was about $15 \%$ below this standard. Concentrate components were chosen so as to bring about an amino acid composition that deviates clearly from high quality protein. In period I the lysine content was $4.0 \mathrm{~g}$ per $16 \mathrm{~g}$ non-ammonia nitrogen, in period V $5.7 \mathrm{~g}$ and in periods III and IV about $2.7 \mathrm{~g}$. In period V an all-grass ration was fed. The grass was fed at intervals from about 7 a.m. to 9 p.m. In periods $I$, III and IV the preliminary feeding periods lasted for 10 days and in period $V$ for 5 days (this short preliminary period was taken as it was intended primarily to measure the absorption of magnesium shortly after a change over of the ration to grass). The experimental period normally lasted 7 days, except in period I ( 5 days). Contents from the proximal duodenum, and distal ileum were sampled every 2 hours for 5 days ( 60 samples from each cow). The samples taken via each fistula were bulked separately and stored at $4^{\circ} \mathrm{C}$. Phenol was added as a preservative.

The rates of flow of digesta were measured by reference to the indicators chromiumsesquioxide $\left(\mathrm{Cr}_{2} \mathrm{O}_{3}\right)$ and poly(ethylene glycol) (PEG). In the calculations the flow rate used was the mean of two values, one based on total $\mathrm{Cr}_{2} \mathrm{O}_{3}$ and the other on PEG. The

Table 1. Components of the rations ( $\mathrm{kg} /$ day fed within each period; $\mathrm{Z}$ and $\mathrm{W}$ are the cows used in the experiments.

\begin{tabular}{|c|c|c|c|c|c|c|c|c|}
\hline & \multicolumn{2}{|c|}{ Period I } & \multicolumn{2}{|c|}{ Period III } & \multicolumn{2}{|c|}{ Period IV } & \multicolumn{2}{|c|}{ Period V } \\
\hline & $\mathbf{Z}$ & W & $\mathbf{Z}$ & W & $\mathbf{Z}$ & W & $\mathrm{Z}$ & W \\
\hline Hay & 8.00 & 7.00 & 3.00 & 3.00 & 3.00 & 3.00 & & \\
\hline $\begin{array}{l}\text { Cellulose } \\
\text { (as paper pulp) }\end{array}$ & & & 4.00 & 3.00 & 4.00 & 3.00 & & \\
\hline Grass & & & & & & & $73.25^{1}$ & $64.49^{2}$ \\
\hline Maize meal & 3.43 & 3.43 & & & 0.30 & 0.30 & & \\
\hline Soya meal & 0.86 & 0.86 & & & & & & \\
\hline Linseed meal & 0.86 & 0.86 & & & & & & \\
\hline Coconut meal & 0.86 & 0.86 & 1.00 & 1.00 & 0.25 & & & \\
\hline Groundnut meal & & & 0.50 & 0.50 & 0.25 & & & \\
\hline Gluten & & & 1.50 & 1.50 & 1.00 & 1.00 & & \\
\hline Gluten meal & & & & 0.50 & & 0.50 & & \\
\hline Maize starch & & & & & 1.30 & 1.30 & & \\
\hline Mineral mixture & & & 0.20 & 0.20 & 0.20 & 0.20 & & \\
\hline
\end{tabular}

$1 \mathrm{~d} . \mathrm{m} .11 .10 \mathrm{~kg} / \mathrm{day}$

'd.m. $9.80 \mathrm{~kg} / \mathrm{day}$. 
experimental and analytical techniques were described more extensively in an earlier paper (van 't Klooster and Rogers, 1969).

The feed and digesta samples were hydrolysed with $6 \mathrm{~N} \mathrm{HCl}$ by heating under reflux in an oil bath at $130^{\circ} \mathrm{C}$ for $22 \mathrm{~h}$. The hydrolysates were evaporated to dryness and transferred to $25-\mathrm{ml}$ flasks and brought to volume. $\alpha$-amino $\mathrm{N}$ was determined according to van Slyke et al. (1941) by distilling $\mathrm{CO}_{2}$ from the hydrolysate in the presence of citrate buffer and ninhydrin reagent. Ammonia was analysed by the method of Conway (1950). Amino acids were determined by means of an automatic amino acid analyser (Phoenix-M 1800, two column system).

In the present paper stomachs refer to the whole ruminant stomach: rumen, reticulum, omasum and abomasum. Small intestine refers to the intestine between the proximal duodenal fistula and the distal ileal fistula, and large intestine to the part of the gut distal to the ileal fistula.

Net absorption is defined as absorption minus endogenous addition.

\section{Results}

\section{Total $N$ and ammonia $N$}

The daily intake of $N$ provided by the various rations in this study ranged from 161 to $330 \mathrm{~g}$ in cow $\mathrm{Z}$ and from 149 to $293 \mathrm{~g}$ in cow W.

The quantities of different $\mathrm{N}$ fractions in rations, duodenal contents, ileal contents and in faeces of the four experimental periods are given in Table 2. Negligible amounts of ammonia $\mathrm{N}$ were found in feedstuffs, ileal contents and faeces. In duodenal contents the quantities of ammonia $\mathrm{N}$ varied from 1 to $9 \%$ of the total $\mathrm{N}$. No special precautions were taken to prevent losses of ammonia during collecting and preparing the samples. Losses of ammonia from duodenal contents are unlikely because of the low

Table 2. The quantities of total nitrogen (N) and non-ammonia $N$ (NAN) and the proportions of $\alpha$-amino $N$ in feed, digesta and faeces of cows $Z$ and $W$ in the four experimental periods.

\begin{tabular}{|c|c|c|c|c|c|c|c|c|}
\hline & \multicolumn{2}{|c|}{ Period I } & \multicolumn{2}{|c|}{ Period III } & \multicolumn{2}{|c|}{ Period IV } & \multicolumn{2}{|c|}{ Period V } \\
\hline & $\mathbf{Z}$ & W & $\mathbf{Z}$ & W & $\mathbf{Z}$ & W & $\mathbf{Z}$ & W \\
\hline \multicolumn{9}{|l|}{ Total $N$ (g/day) } \\
\hline intake & 304 & 289 & 228 & 250 & 162 & 150 & 332 & 295 \\
\hline duodenal contents & 332 & 285 & 264 & 309 & 224 & 203 & 337 & 268 \\
\hline ileal contents & 123 & 107 & 75 & 86 & 83 & 75 & 103 & 99 \\
\hline faeces & 105 & 95 & 66 & 74 & 76 & 67 & 76 & 69 \\
\hline \multicolumn{9}{|l|}{$N A N(g /$ day $)$} \\
\hline intake & 363 & 288 & 227 & 248 & 161 & 149 & 330 & 293 \\
\hline duodenal contents & 324 & 279 & 256 & 302 & 222 & 201 & 308 & 260 \\
\hline ileal contents & 122 & 106 & 74 & 84 & 83 & 74 & 102 & 96 \\
\hline faeces & 104 & 94 & 65 & 73 & 75 & 66 & 75 & 68 \\
\hline \multicolumn{9}{|l|}{$\alpha$-amino $N(\%$ of $N A N)$} \\
\hline intake & 67 & 66 & 74 & 72 & 72 & 72 & 58 & 58 \\
\hline duodenal contents & 66 & 65 & 64 & 62 & 69 & 63 & 64 & 61 \\
\hline ileal contents & 57 & 55 & 56 & 54 & 58 & 58 & 56 & 57 \\
\hline feaces & 59 & 59 & 57 & 56 & 59 & 60 & 55 & 55 \\
\hline
\end{tabular}


Table 3. Digestion of organic matter (OM) and crude protein along the gut of cows $\mathrm{Z}$ and $\mathrm{W}$ and the disappearance or net absorption of non-ammonia $\mathrm{N}$ (NAN) and $\alpha$-amino $\mathrm{N}$ from the small intestine.

\begin{tabular}{|c|c|c|c|c|c|c|c|c|}
\hline & \multicolumn{2}{|c|}{ Period I } & \multicolumn{2}{|c|}{ Period IV } & \multicolumn{2}{|c|}{ Period III } & \multicolumn{2}{|c|}{ Period V } \\
\hline & $\mathbf{Z}$ & W & $\mathbf{Z}$ & W & $\mathbf{Z}$ & W & $\mathbf{Z}$ & W \\
\hline $\mathrm{OM}$ digestibility $^{1}(\%)$ & 68 & 70 & 79 & 76 & 70 & 72 & 80 & 80 \\
\hline OM digested ( $\mathrm{kg} /$ day) in: & & & & & & & & \\
\hline gut & 7.87 & 7.45 & 7.05 & 6.38 & 6.37 & 5.81 & 8.21 & 7.32 \\
\hline stomachs & 4.93 & 4.92 & 5.04 & 4.20 & 4.42 & 4.23 & 5.62 & 4.96 \\
\hline small intestine & 2.12 & 2.07 & 1.63 & 1.82 & 1.38 & 1.29 & 1.86 & 1.82 \\
\hline $\begin{array}{l}\text { Crude protein (NAN } \times 6.25 \text { ) } \\
\text { digested in small intestine }\end{array}$ & & & & & & & & \\
\hline $\begin{array}{l}\text { in } \mathrm{kg} / \text { day } \\
\text { in } \% \text { of } \mathrm{OM} \text { digested in }\end{array}$ & 1.25 & 1.07 & 1.13 & 1.34 & 0.86 & 0.78 & 1.28 & 1.01 \\
\hline the small intestine & 59 & 52 & 69 & 74 & 62 & 61 & 69 & 57 \\
\hline $\begin{array}{l}\text { Dietary } \mathrm{N} \text { in } \% \text { of } \mathrm{OM} \\
\text { digested in the }\end{array}$ & 3.84 & 380 & 3.46 & 4.01 & 254 & 255 & 404 & 403 \\
\hline $\begin{array}{l}\text { NAN of duodenal contents } \\
\text { in \% of OM digested in the }\end{array}$ & 412 & 375 & 3.40 & 4.01 & 2.044 & $2 ., 3$ & 4.04 & 4.03 \\
\hline $\begin{array}{l}\text { Disappearance from the small } \\
\text { intestine in } \% \text { of amount } \\
\text { in duodenal contents } 1\end{array}$ & 4.12 & 5.15 & 3.04 & 4.74 & 3.40 & 5.40 & 0.13 & 3.50 \\
\hline NAN & 61 & 61 & 70 & 71 & 62 & 62 & 66 & 62 \\
\hline$\alpha$-amino $\mathrm{N}$ & 66 & 66 & 73 & 75 & 68 & 65 & 71 & 67 \\
\hline
\end{tabular}

pH (about 2.5). However, small losses of ammonia from ileal contents and faeces can not be excluded.

The quotient of amount of non-ammonia $N$ (NAN) in duodenal contents to amount of $\mathrm{N}$ ingested in each experimental period was for a ration of hay and concentrate (period I) 1.01, for a semisynthetic ration adequate in $\mathrm{N}$ (period III) 1.17 , for a semisynthetic ration low in $\mathrm{N}$ (period IV) 1.37, and for a grass ration (period V) 0.91. A loss of NAN was found with the animals on the grass ration only. In this period the NAN intake was highest.

The net absorption of NAN from the small intestine amounted to about $63 \%$ of the quantities in duodenal contents in periods I, IV and V and to about $72 \%$ in period III (Table 3). A further net absorption of NAN was noticed from the caecum and large intestine varying from 3.5 to $5.6 \%$ of the NAN in duodenal contents in periods I, III and IV. Higher percentages were found in period V, namely 7.8 for cow $Z$ and 10.9 for cow W.

\section{$\alpha$-amino nitrogen}

In hydrolysates of feedstuffs, digesta and faeces the contents of $\alpha$-amino $\mathrm{N}$ were determined. During hydrolysis with $6 \mathrm{~N} \mathrm{HCl}$ part of the amino acids are destroyed (i.e. tryptophan and cystine). Therefore, the amounts of $\alpha$-amino $N$ calculated from the contents in the hydrolysates are minimal. In Table 2 the quantities of $\alpha$-amino $\mathrm{N}$ are expressed as percentages of NAN. High percentages indicate that a high proportion of the NAN was contained in amino acids, and reverse. 
The variation in the proportions of $\alpha$-amino $N$ in digesta samples was smaller than in the rations. In duodenal contents more of the NAN was $\alpha$-amino $N$ than of the NAN in ileal conents and faeces $(P<0.01)$. In hay fed in periods I, III and IV about $65 \%$ of NAN was found to be $\alpha$-amino $\mathrm{N}$, while for the grass fed in period $\mathrm{V}$ a percentage of 58 was calculated. This is in accordance with the finding that heavily fertilized pastures do contain a relatively high proportion of non-protein $\mathbf{N}$ (Nowakowski, 1962).

The disappearance of $\alpha$-amino $\mathrm{N}$ from the small intestine can be considered as a measure of the net absorption of protein $\mathrm{N}$. On average about $70 \%$ of the $\alpha$-amino $\mathrm{N}$ present in duodenal digesta had disappeared in the distal ileum. Period III showed somewhat higher percentages than the other periods (Table 3).

The mean value with standard deviation for net absorption of $\alpha$-amino $\mathrm{N}$ in the small intestine $(70 \pm 4 \%$ ) was higher $(P<0.01)$ than that for NAN $(65 \pm 4 \%)$. The difference can not be ascribed to nucleic acids N, as RNA and DNA are found to be highly digested (Smith and McAllan, 1971) and absorbed (Condon and Hatfield, 1971). The difference may be due to the increasing preponderance of bacterial cell wall substances (Hoogenraad and Hird, 1970) in ileal contents and to an increase in concentration of amino sugars (Badaway and Cuthbertson, 1964). The presence of bile constituents in ileal contents may also have contributed to this difference. Bile pigments are added to the digesta distal to the duodenal fistula and only a small fraction is absorbed from the small intestine.

\section{Protein and organic matter digestion}

It has been suggested that the synthesis of microbial protein in the rumen is usually limited by the energy available for microbial growth. This energy is released in the rumen by the anaerobic breakdown of organic matter (OM). In the present experiments $4.79 \pm 0.48 \mathrm{~kg}$ of $\mathrm{OM}$ disappeared proximal to the duodenum. OM of duodenal digesta consists of a mixture of undigested dietary $\mathrm{OM}$, microbial $\mathrm{OM}$ and endogenous $\mathrm{OM}$ of different sources. Therefore, the actual quantities of $\mathrm{OM}$ digested in the rumen were higher than those given in Table 3.

In the present experiments the partial digestion of digestible $O M$ was $68 \pm 3 \%$ in the stomach, $25 \pm 3 \%$ in the small intestine, and $7 \pm 2 \%$ in the large intestine. Of the OM digested in the small intestine about two thirds $(63 \pm 7 \%)$ could be accounted for as crude protein (NAN $\times 6.25$ ).

As it is difficult to predict from data on $\mathrm{N}$ intake the amount of crude protein that enters the small intestine of ruminants, it would be useful to find parameters for the prediction of this amount. As such the digestible OM would be most convenient. In the present experiments the NAN in duodenal digesta represented on average $3.84 \pm 0.430 \%$ of the $\mathrm{OM}$ digested in the gastro-intestinal tract. The variance was considerable. In one experiment (period II, W) the NAN of duodenal contents amounted to $4.77 \%$ of the digested OM. If this high value was omitted from the comparison a fairly constant percentage of the OM digested was calculated as NAN $(3.68 \pm 23 \%)$.

The quantities of dietary $\mathrm{N}$ per $100 \mathrm{~g}$ digested organic matter (DOM) (Table 3) varied considerably more $(3.54 \pm 0.64)$ than the quantities of duodenal NAN per $100 \mathrm{~g}$ DOM. This shows the levelling effect of microbial protein metabolism on the quantity of protein entering the small intestine.

Hogan and Weston (1970) reported that the quantity of $\mathrm{N}$ other than ammonia $\mathrm{N}$ that passed from the stomach of sheep fed dried forages exceeded $\mathrm{N}$ intake when the dietary $\mathrm{N}$ was less than $4 \%$ of the DOM and was less than intake with diets containing higher proportions of $\mathrm{N}$. In agreement with this the present results (Table 3) showed an 
increase in total $\mathrm{N}$ passing to the duodenum when $\mathrm{N}$ intake was less than $4 \mathrm{~g} / 100 \mathrm{~g}$ DOM, and a small decrease at an intake of just over $4 \mathrm{~g} \mathrm{~N} / 100 \mathrm{~g} \mathrm{DOM}$.

\section{Amino acids}

Table 4 gives the total quantities of individual amino acids determined in the rations, duodenal contents and ileal contents of cows $\mathrm{Z}$ and $\mathrm{W}$ on four different rations. The amino acids are classified into two groups. Group 1 contains the amino acids which are required by the growing rat, except tryptophan, but with the addition of tyrosine and arginine. The latter two and cystine are considered semi-indispensable to the rat. Tryptophan (indispensable) was destroyed during the hydrolytic procedure and only a part of cyst(e)ine (semi-indispensable) survived. Studies of Black et al. (1957), Downes (1961) and of Shingoethe et al. (1967) provide some evidence that amino acids of group 1 are metabolically essential to the ruminant animal.

Mean values for total amino acids, group 1 and group 2 amino acids, fed, entering

Table 4. The quantities ( $\mathrm{g} /$ day) of 15 amino acids in the rations fed $(\mathrm{R})$, duodenal digesta (D) and ileal digesta (I) of cow $Z$ and $W$ in four experimental periods.

\begin{tabular}{|c|c|c|c|c|c|c|c|c|c|c|c|c|c|}
\hline & & \multicolumn{3}{|c|}{ Period I } & \multicolumn{3}{|c|}{ Period III } & \multicolumn{3}{|c|}{ Period IV } & \multicolumn{3}{|c|}{ Period V } \\
\hline & & $\mathbf{R}$ & $\mathrm{D}$ & I & $\mathbf{R}$ & D & I & $\mathbf{R}$ & $\mathrm{D}$ & I & $\mathbf{R}$ & $\mathrm{D}$ & I \\
\hline \multicolumn{14}{|c|}{ Group 1} \\
\hline \multirow[t]{2}{*}{ Lys } & $\mathbf{Z}$ & 74 & 111 & 28 & 38 & 80 & 21 & 29 & 71 & 16 & 113 & 112 & 28 \\
\hline & W & 70 & 104 & 23 & 39 & 85 & 20 & 25 & 62 & 12 & 100 & 110 & 20 \\
\hline \multirow[t]{2}{*}{ His } & $\mathbf{Z}$ & 44 & 42 & 11 & 27 & 33 & 7 & 18 & 31 & 7 & 40 & 37 & 8 \\
\hline & W & 42 & 42 & 9 & 26 & 38 & 10 & 17 & 24 & 7 & 35 & 35 & 6 \\
\hline \multirow[t]{2}{*}{ Thr } & $\mathbf{Z}$ & 75 & 100 & 35 & 50 & 76 & 21 & 32 & 60 & 18 & 86 & 94 & 21 \\
\hline & W & 71 & 83 & 30 & 49 & 84 & 24 & 36 & 47 & 17 & 76 & 82 & 20 \\
\hline \multirow[t]{2}{*}{ Val } & $\mathbf{Z}$ & 94 & 106 & 36 & 72 & 89 & 21 & 45 & 64 & 20 & 116 & 92 & 24 \\
\hline & W & 88 & 94 & 28 & 66 & 91 & 26 & 42 & 53 & 17 & 103 & 88 & 18 \\
\hline \multirow[t]{2}{*}{ Met } & $\mathbf{Z}$ & 32 & 40 & 11 & 24 & 35 & 9 & 18 & 34 & 8 & 35 & 32 & 7 \\
\hline & W & 30 & 45 & 10 & 26 & 33 & 9 & 17 & 26 & 6 & 31 & 25 & 8 \\
\hline \multirow[t]{2}{*}{ Ile } & $\mathbf{Z}$ & 73 & 108 & 25 & 49 & 67 & 17 & 38 & 63 & 16 & 82 & 89 & 20 \\
\hline & $\mathbf{W}$ & 69 & 86 & 23 & 50 & 91 & 19 & 35 & 51 & 14 & 73 & 76 & 16 \\
\hline \multirow[t]{2}{*}{ Leu } & $\mathbf{Z}$ & 146 & 163 & 40 & 144 & 142 & 25 & 100 & 126 & 22 & 159 & 141 & 33 \\
\hline & W & 139 & 147 & 35 & 144 & 167 & 31 & 93 & 100 & 21 & 141 & 121 & 27 \\
\hline \multirow[t]{2}{*}{ Tyr } & $\mathbf{Z}$ & 59 & 95 & 21 & 52 & 81 & 13 & 23 & 59 & 12 & 59 & 85 & 20 \\
\hline & W & 56 & 65 & 18 & 53 & 89 & 17 & 20 & 35 & 9 & 52 & 68 & 13 \\
\hline \multirow[t]{2}{*}{ Phe } & $\mathbf{Z}$ & 93 & 100 & 40 & 73 & 84 & 23 & 50 & 75 & 14 & 96 & 98 & 39 \\
\hline & W & 88 & 87 & 34 & 72 & 93 & 24 & 45 & 47 & 13 & 85 & 93 & 35 \\
\hline \multirow[t]{2}{*}{ Arg } & $\mathbf{Z}$ & 109 & 95 & 18 & 86 & 53 & 11 & 52 & 62 & 9 & 120 & 86 & 11 \\
\hline & $\mathbf{W}$ & 105 & 81 & 17 & 86 & 59 & 10 & 37 & 42 & 8 & 107 & 70 & 11 \\
\hline \multicolumn{14}{|c|}{ Group 2} \\
\hline \multirow[t]{2}{*}{ Asp } & $\mathbf{Z}$ & 168 & 207 & 56 & 122 & 152 & 29 & 83 & 108 & 34 & 186 & 185 & 43 \\
\hline & W & 158 & 158 & 48 & 117 & 160 & 43 & 74 & 90 & 31 & 165 & 161 & 34 \\
\hline \multirow[t]{2}{*}{ Ser } & $\mathbf{Z}$ & 88 & 91 & 29 & 67 & 73 & 17 & 44 & 59 & 16 & 78 & 80 & 19 \\
\hline & W & 84 & 71 & 26 & 64 & 82 & 20 & 41 & 48 & 15 & 69 & 64 & 17 \\
\hline \multirow[t]{2}{*}{ Glu } & $\mathbf{Z}$ & 284 & 293 & 89 & 246 & 281 & 54 & 161 & 229 & 50 & 217 & 214 & 65 \\
\hline & $\mathbf{W}$ & 273 & 269 & 86 & 236 & 312 & 63 & 149 & 167 & 44 & 193 & 201 & 49 \\
\hline \multirow[t]{2}{*}{ Gly } & $\mathbf{Z}$ & 89 & 111 & 36 & 49 & 81 & 21 & 34 & 67 & 19 & 96 & 86 & 24 \\
\hline & W & 84 & 90 & 36 & 49 & 95 & 28 & 32 & 54 & 22 & 85 & 84 & 21 \\
\hline \multirow[t]{2}{*}{ Ala } & $\mathbf{Z}$ & 87 & 128 & 32 & 53 & 102 & 25 & 36 & 58 & 24 & 144 & 121 & 27 \\
\hline & $\mathbf{W}$ & 83 & 100 & 27 & 52 & 120 & 34 & 36 & 54 & 18 & 128 & 100 & 20 \\
\hline
\end{tabular}


Table 5. The amounts ( $\mathrm{g} /$ day) of amino acids (sum of 15 amino acids) in rations (R), duodenal digesta (D) and ileal digesta (I), the percentage of increase at the duodenum and the net absorption from the small intestine. The results for group 1 and group 2 amino acids (see Table 4) are given separately.

\begin{tabular}{|c|c|c|c|c|c|c|c|c|c|c|c|c|}
\hline & \multicolumn{3}{|c|}{ Period I } & \multicolumn{3}{|c|}{ Period III } & \multicolumn{3}{|c|}{ Period IV } & \multicolumn{3}{|c|}{ Period V } \\
\hline & $\mathbf{R}$ & D & I & $\mathbf{R}$ & $\mathrm{D}$ & I & , $\mathrm{R}$ & D & $\mathrm{I}$ & $\mathbf{R}$ & $\mathbf{D}$ & I \\
\hline Total amino acids & 1472 & 1656 & 478 & 1140 & 1514 & 360 & 731 & 1033 & 269 & 1535 & 1465 & 352 \\
\hline group 1 & 774 & 897 & 246 & 613 & 785 & 179 & 386 & 566 & 133 & 854 & 817 & 193 \\
\hline group 2 & 699 & 759 & 232 & 528 & 729 & 181 & 345 & 467 & 136 & 680 & 648 & 159 \\
\hline \\
\hline total amino acids & \multicolumn{3}{|c|}{+12.4} & \multicolumn{3}{|c|}{+32.7} & \multicolumn{3}{|c|}{+41.3} & \multicolumn{3}{|c|}{-4.7} \\
\hline group 1 & \multicolumn{3}{|c|}{+15.9} & \multicolumn{3}{|c|}{+28.0} & \multicolumn{3}{|c|}{+46.6} & \multicolumn{3}{|c|}{-4.5} \\
\hline group 2 & \multicolumn{3}{|c|}{+8.5} & \multicolumn{3}{|c|}{+38.1} & \multicolumn{3}{|c|}{+35.3} & \multicolumn{3}{|c|}{-5.0} \\
\hline \multicolumn{13}{|l|}{$\begin{array}{l}\text { Net absorption } \\
\text { small intestine }{ }^{1}\end{array}$} \\
\hline total amino acids & & & 70 & & & 75 & & & 73 & & & 75 \\
\hline group 1 & & & 72 & & & 76 & & & 76 & & & 75 \\
\hline group 2 & & & 68 & & & 74 & & & 70 & & & 74 \\
\hline
\end{tabular}

${ }^{1}$ Corrected for subtraction of duodenal samples (1\%).

and leaving the small intestine are presented in Table 5. Increases in the quantities of amino acids at the proximal duodecum were seen in period I, III and IV, with the greatest increases in period IV. In period V, when an all-grass ration was fed, the quantities of amino acids entering the small intestine were on average about $5 \%$ lower than ingested. Differences between group 1 and group 2 amino acids were not consistent.

The mean net absorption of total acids in the small intestine, calculated as the quantity disappearing in the small intestine as a percentage of the quantity entering, varied from 69 to $76 \%$. The means for the two cows are given in Table 5. Group I amino acids showed a significantly $(\mathrm{P}<0.01)$ higher net absorption percentage than group 2 amino acids (difference $3 \pm 2 \%$ ).

Of the amino acids analysed a greater proportion disappeared between duodenum and caecum than of the $\alpha$-amino $\mathrm{N}(74 \pm 3 \%$ and $70 \pm 4 \%$ of the quantities in duodenal contents, respectively). The difference was found to be significant $(P<0.01)$. That ileal contents contained relatively more $\alpha$-amino $\mathrm{N}$ not accounted for in the 15 amino acids determined than duodenal conents, can be ascribed at least partly to the relative increase of amino acids as proline and cystine not determined in the present experiments. In the experiments of Clarke et al. (1966) the proportion of cystine and proline increased during the passage along the small intestine.

Fig. 1 shows graphically the relative amounts of each individual amino acid fed, reaching the small intestine and leaving it, expressed as percentages of the quantities fed. Increases at the proximal duodenum of more than $50 \%$ (averages for periods I, III and IV) were found for lysine, tyrosine, alanine, glycine and isoleucine. Threonine, methionine and histidine showed increases of more than $25 \%$. Decreases were found for arginine (periods $\mathrm{I}$ and III) and for serine (period I). In period V only for tyrosine was the amount entering the small intestine more than the amount ingested. Amounts of other amino acids stayed the same or decreased.

Microbial activity in the reticulo-rumen resulted in considerable changes in the quantities of individual amino acids (Table 4). It also transformed the diversity of protein 
A. TH. VAN 'T KLOOSTER AND H. A. BOEKHOLT
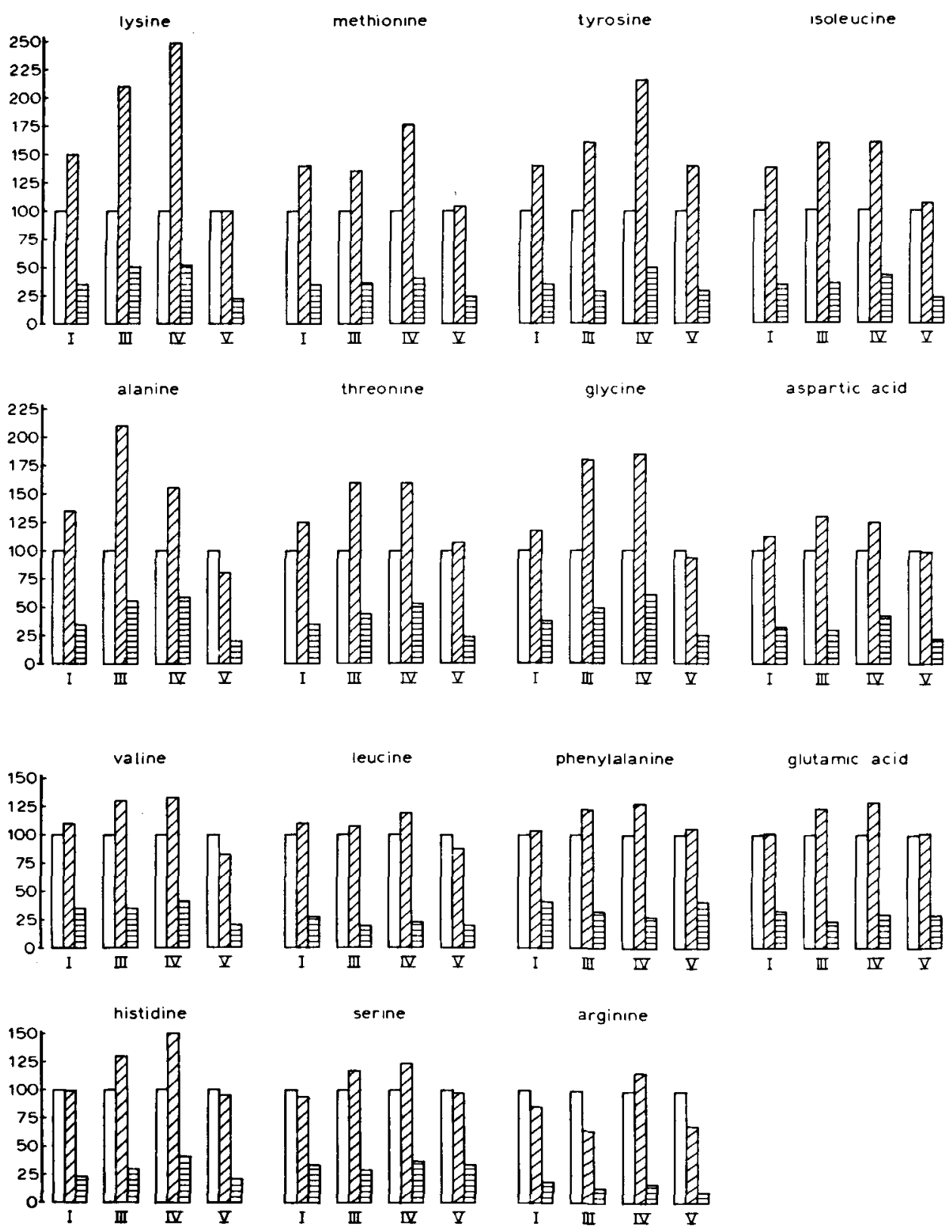

Fig. 1. The relative amounts of amino acids in feed $(=100)$ (left one of each set of columns), duodenal contents (middle one) and ileal contents (right one) in periods I, III, IV and V, expressed as a percentage of the amounts fed. 
quality in the rations to a more uniform product passing to the intestines. In the present experiments this is best illustrated with the contents of lysine in rations and duodenal digesta. The lysine content of the rations fed in period I, III, IV and V were 4.0, $2.6,2.8$ and $5.7 \mathrm{~g}$ per $16 \mathrm{~g} \mathrm{NAN}$, respectively; in duodenal digesta these values were on average 5.8, 4.8, 5.0 and 6.2, respectively. Nevertheless, the important levelling effect of microbial activity did not compensate fully the considerable differences in lysine content of the rations.

Digestion and synthesis in the stomach thus modified the total amounts of amino acids passing to the small intestine. It also changes the relative proportions of indivudual amino acids (amount of individual amino acid as a percentage of total amino acids determined). Of the total amounts of amino acids determined to pass to the duodenum the proportions of several amino acids increased significantly, i.e. lysine $(P<0.01)$, theonine $(\mathrm{P}<0.01)$, isoleucine $(\mathrm{P}<0.01)$, tyrosine $(\mathrm{P}<0.01)$ and glycine $(\mathrm{P}<0.05)$. Decreases of the proportions of leucine $(\mathrm{P}<0.01$, ) arginine $(\mathrm{P}<0.01)$, glutamic acid $(\mathrm{P}<0.05)$, valine $(\mathbf{P}<0.05)$ and serine $(\mathbf{P}<0.05)$ were noted, while the proportions of other amino acids showed non-significant changes. The present results agreed with the findings of Clarke et al. (1966) in experiments with sheep. Dirksen et al. (1972) reported from experiments with (re-entrant) fistulated cows decreases in the relative proportions of glutamic acid, valine and leucine.

At passing through the small intestine further changes in the relative proportions of some amino acids occurred. Increases of the proportions of threonine $(P<0.05)$, serine $(\mathrm{P}<0.05)$, and especially of glycine $(\mathrm{P}<0.01)$ were found; significant decreases were noted for leucine $(\mathrm{P}<0.01)$, tyrosine $(\mathrm{P}<0.01)$ and arginine $(\mathrm{P}<0.01)$.

\section{Discussion}

It has been well established in experiments with sheep that with diets of low protein content a gain of $\mathrm{N}$ may occur as the digesta pass through the stomach because of microbial protein synthesis from endogenous $\mathrm{N}$, whereas with diets of higher protein content a wastage of $\mathrm{N}$ may occur through the absorption of ammonia from the stomach after the desamination of amino acids (Gray et al., 1958; Hogan, 1965; Sharma et al., 1969; Weston and Hogan, 1968; Hume et al., 1970). The endogenous N, transferred to the reticulo-rumen mostly as urea $\mathrm{N}$, is derived both from saliva and by direct passage through the rumen wall (Vercoe, 1969). The secretion of gastric juice and the sloughing of epithelial cells and mucus in the abomasum make a further contribution of $N$ compounds to the digesta entering the duodenum. Weston and Hogan (1967) estimated the secretion of $\mathrm{N}$ in the abomasum of sheep at about $1 \mathrm{~g}$ per day, while Clarke et al. (1966) came to a value of about $2 \mathrm{~g}$ per day. There is no information on the $\mathrm{N}$ content of gastric juice of cows, nor on the gastric juice secretion. Assuming a similar $\mathrm{N}$ content as in gastric juice of sheep, the quantity of $\mathrm{N}$ secretion in the abomasum of cows can be roughly estimated at 15 to $30 \mathrm{~g}$ per day or about 15 times as much as secreted in sheep gastric juice. With this in mind we can conclude that degradation of dietary protein and synthesis of microbial protein in the reticulo-rumen resulted in no change in period I, an increase in period III and IV, and a decrease in period V, in the quantity of protein entering the small intestine.

The main nitrogenous components in the digesta passing to the small intestine are $\alpha$-amino $\mathrm{N}$, non- $\alpha$-amino $\mathrm{N}$, nucleic acid $\mathrm{N}$, amide $\mathrm{N}$ and a variable proportion of ammonia $\mathrm{N}$. About $64 \%$ of NAN in duodenal digesta was found to be $\alpha$-amino $\mathrm{N}$. 
Basic amino acids and tryptophan do contain non- $\alpha$-amino $\mathrm{N}$ which contributes about $12 \%$ of the NAN in duodenal digesta (in the rations a somewhat higher percentage $(14 \%)$ was found because of the high arginine content). Nucleic acid $\mathrm{N}$ constitutes another $8-13 \%$ of the NAN in duodenal digesta (Ellis and Pfander, 1965; Smith and McAllan, 1970). The rest is chiefly amide N. In the present experiments the proportion of amino acid $\mathrm{N}$ was close to $80 \%$ of the NAN in duodenal digesta.

The main sources of NAN in digesta entering the duodenum are microbial protein synthetized in the reticulo-rumen and dietary protein. From the results presented it is not possible to calculate the proportions of dietary $\mathrm{N}$ and microbial $\mathrm{N}$ in the NAN leaving the stomach. However, the extent of bacterial $\mathbf{N}$ synthesis in the rumen is likely to be determined by the amount of energy released during the fermentation of the diet in the rumen. Hogan and Weston (1970) calculated from a series of experiments with sheep fed forages that the extent of bacterial $\mathrm{N}$ synthesis would probably be less than $3.7 \mathrm{~g} \mathrm{~N}$ per $100 \mathrm{~g} \mathrm{OM}$ apparently digested in the stomach. This value is now considered not to be a maximum. In a recent study they calculated values of about $4 \mathrm{~g} \mathrm{~N}$ per $100 \mathrm{~g}$ OM digested in the stomach (Hogan and Weston, 1971). If it is assumed that in our experiments the efficiency of conversion was $3.7 \mathrm{~g} \mathrm{~N}$ per $100 \mathrm{~g} \mathrm{OM}$ apparently disgested in the stomach, it may be estimated from data presented in Table 3 that bacterial $N$ was equivalent to $61,62,76$ and $69 \%$ of the NAN in dudenal digesta in period I, III, IV and $\mathrm{V}$, respectively (averages of the two cows). These percentages are in the range of those found by Weller et al. (1958) for the proportions of microbial $\mathrm{N}$ in rumen contents of sheep. They measured the contribution of bacterial $\mathrm{N}$ to total $\mathrm{N}$ in rumen contents with diamino pimelic acid (DAP) as a bacterial marker. With the same technique Hutton et al. (1971) found that half the $N$ leaving the stomach of a cow fed on barley straw and concentrates $(6.64 \mathrm{~kg} /$ day $)$ was of bacterial origin. The considerably higher proportions of bacterial $\mathrm{N}$ estimated in duodenal digesta of our cows in period IV are explainable by the relative small amounts of $\mathrm{N}$ ingested in relation to the amounts of NAN in duodenal digesta.

Protozoa contribute also to the protein in duodenal contents. Little is known about the relative contributions of bacteria and protozoa to the total synthesized protein entering the small intestine. Estimates of the bacterial and protozoal contents of rumen digesta indicate, however, that these relative contributions could be markedly affected by the nature of the diet (Weller et al., 1969; Höller and Harmeyer, 1964).

The amino acid composition of rumen bacteria and of protozoa in relation to the diet fed have recently been discussed by Purser (1970) and Ibrahim and Ingalls (1972).

Clarke et al. (1966) discussed the absorption of individual amino acids from the small intestine. Purser (1970) recalculated from data presented by Clarke et al. (1966) that a greater relative quantity of essential amino acids than unessential amino acids was absorbed in the small intestine. This has been confirmed recently by Coelho da Silva et al. (1972). The difference in the percentage of net absorption of group 1 and group 2 amino acids in the present experiments show also a greater net absorption of essential amino acids. However, of the latter amino acids threonine, valine and phenylalanine showed a smaller net absorption than the mean for total amino acids determined. Of group 2 amino acids glycine and alanine showed the smallest net absorption percentages. With the technique used only the balance between amino acids added to and absorbed from the small intestine was measured. Secretion products, mucus and desquamated mucosal cells are being added to the digesta as it passes down the rumen. The differences seen in the net absorption percentages may reflect differences in the true absorption rate (Nixon and Mawer, 1970) but can be caused also by differences in the quantities added. 
Nitrogenous compounds which escape hydrolytic digestion in the small intestine, enter the large intestine and are exposed to the action of a wider spectrum of enzymes produced by the microflora. That breakdown of proteins occurs in caecum and large intestine is strongly suggested by the ammonia production measured in these organs (Hecker, 1971). Absorption of ammonia (McDonald, 1948) and other nitrogen compounds from the large intestine has been measured. It is unlikely that the losses of $\mathrm{N}$ from the large intestine in the present experiments (van 't Klooster and Rogers, 1969) represented a significant absorption of amino acids.

\section{Acknowledgements}

We gratefully acknowledge Mr N. F. M. Thielen for analytical assistance, Mr C. R. Vonk of the Centre for Plant Physiological Research in Wageningen for the amino acid analyses and $\mathrm{Mr}$ G. A.Bangma for co-operation in the digesta sampling.

We wish to thank Dr R. M. Koes for correcting the English text.

\section{References}

Allison, M. J., 1970. Nitrogen metabolism of ruminal micro organisms. In: A. T. Phillipson (Ed.), Physiology of digestion and metabolism in the ruminant. Oriel Press, Newcastle upon Tyne.

Badaway, A. M. \& D. P. Cuthbertson, 1964. Significance of changes in hexosamine and in nitrogen in the digesta of the alimentary tract of the sheep. Q. J. exp. Physiol. 49: 349.

Black, A. L., M. Kleiber, H. M. Smith \& D. N. Steward, 1957. Acetate as a precursor of amino acids of casein in the intact dairy cow. Biophys. Acta 23: 54.

Blackburn, T. H., 1965. Nitrogen metabolism in the rumen. R. W. Dougherty (Ed.), Physiology of digestion in the ruminant, p. 322. Butterworths, Washington.

Chalupa, W., 1972. Metabolic aspects of non protein nitrogen utilization in ruminant animals. Fedn Proc. Fedn Am. Socs exp. Biol. 31: 1152.

Clarke, Eileen M. W., Gabrielle M. Ellinger \& A. T. Phillipson, 1966. The influence of diet on the nitrogenous components passing to the duodenum and through the lower ileum of sheep. Proc. $R$. Soc. B. 166: 63 .

Coelho da Silva, J. F., R. C. Seeley, D. J. Thomson, D. E. Beever \& D. G. Armstrong, 1972. The effect in sheep of physical form on the sites of digestion of a dried lucerne diet. 2. Sites of nitrogen digestion. Br. J. Nutr. 28: 43.

Condon, R. J. \& E. E. Hatfield, 1971. Metabolism of exogenous nucleic acids by ovines. Fedn Proc. Fedn Am. Socs exp. Biol. 30: 403.

Conway, E. J., 1950. Micro diffusion analysis and volumetric error, 3rd ed. Crosby Lockwood, London.

Dirksen, G., W. Kaufmann \& E. Pfeffer, 1972. Untersuchungen zur Verdauungsphysiologie der Milchkuh mit der Umleitungstechnik am Duodenum. In: Fortschritte in der Tierphysiologie und Tierernährung, 1. Supplement to Z. Tierphysiol. Tierernähr. Futtermittelk.

Downes, A. M., 1961. On the amino acids essential for the tissue of the sheep. Aust. J. biol. Sci. 14: 254.

Ellis, W. C. \& W. H. Pfander, 1965. Rumen microbial polynucleotide synthesis and its possible role in ruminant nitrogen utilization. Nature, Lond. 205: 974.

Faichney, G. J., 1968. Volatile fatty acids in the caecum of the sheep. Aust. J. biol. Sci. $21: 177$.

Gray, F., V. Pilgrim \& R. A. Weller, 1958. The digestion of foodstuffs in the stomach of the sheep and the passage of digesta through its compartments. Br. J. Nutr. 12: 404.

Hecker, J. F., 1971. Ammonia in the large intestine of herbivores. Br. J. Nutr. 26: 135.

Hogan, J. P., 1965. The digestion of food by the grazing sheep. III. The quantity of protein reaching the small intestine. Austr. J. agric. Res. 16: 179.

Hogan, J. P. \& R. H. Weston, 1970. Quantitative aspects of microbial protein synthesis in the rumen. In: A. T. Phillipson (Ed.), Physiology of digestion and metabolism in the ruminant, p. 474. Oriel Press, Newcastle upon Tyne. 
Hogan, J. P. \& R. H. Weston, 1971. The utilization of alkali treated straw by sheep. Aust. J. agric. Res. 22: 951.

Höller, H. \& T. Harmeyer, 1964. Nitrogen and amino acid content of rumen protozoa. Zbl. vet. Med., Reihe A 3: 244.

Hoogenraad, N. J. \& F. J. R. Hird, 1970. The chemical composition of rumen bacteria and cell walls from rumen bacteria. Br. J. Nutr. 24: 119 .

Hume, I. D., R. J. Moir \& M. Somers, 1970. Synthesis of microbial protein in the rumen. Aust. J. agric. Res. 21: 283.

Hungate, R. E., 1965. Quantitative aspects of the rumen fermentation. In: R. W. Dougherty (Ed.), Physiology of digestion in the ruminant, p. 311. Butterworths, Washington.

Hutton, K., F. J. Bailey \& E. F. Annison, 1971. Measurement of the bacterial nitrogen entering the duodenum of the ruminant using diaminopimelic acid as a marker. Br. J. Nutr. 25: 165.

Ibrahim, E. A. \& J. R. Ingalls, 1972. Microbial protein biosynthesis in the rumen. J. Dairy Sci. $55: 971$.

Kay, R. N., 1969. Digestion of protein in the intestines of adult ruminants. Proc. Nutr. Soc. $28: 140$.

Klooster, A. Th. van 't \& P. A. M. Rogers, 1969. Observation on the digestion and absorption of food along the gastro-intestinal eract of fistulated cows. 1. The rate of flow of digesta and the net absorption of dry matter, organic matter, ash, nitrogen and water. Meded. LandbHogesch. Wageningen 69-11.

Neudoerffer, T. S., P. A. Leadbeater, F. D. Horney \& H. S. Bayley, 1971. The influence of level of grain intake on protein digestion in the intestine of cattle. Br. J. Nutr. 25: 343 .

Nixon, S. Elizabeth \& G. E. Mawer, 1970. The digestion and absorption of protein in man. 1. The site of absorption; 2. The form in which digested protein is absorbed. Br. J. Nutr. 24: 227.

Nawakowski, T. Z., 1962. Effects of nitrogen fertilizers on total nitrogen, soluble nitrogen and soluble carbohydrate contents of grass. J. agric. Sci. 59: 387.

Purser, D. B., 1970. Nitrogen metabolism in the rumen: Micro-organisms as a source of protein for the ruminant animal. J, Anim. Sci. 30: 988.

Sharma, H. R., A. Th. van 't Klooster \& A. M. Frens, 1969. In vivo measurements of the synthesis of protein from urea in the rumen of sheep. Z. Tierphysiol. Tierernähr. Futtermittelk. 24: 372.

Shingoethe, D. J., E. C. Hageman \& B. L. Larson, 1967. Essential amino acids for milk protein synthesis in the in-vitro secretory call and stimulation by elevated levels. Biochem. biophys. Acta 148: 469 .

Slyke, D. D. van, D. A. McFadyen \& P. Hamilton, 1941. Determination of free amino acid by titration of the $\mathrm{CO}_{2}$ formed in the reaction with ninhidrin. J. biol. Chem.. 141: 671 .

Smith, R. H., 1969. Nitrogen metabolism and the rumen. J. Dairy Res. 36: 313.

Smith, R. H. \& A. B. McAllan, 1970. Nucleic acid metabolism in the ruminant. 2. Formation of microbial nucleic acids in the rumen in relation to the digestion of food nitrogen and the fate of dietary nucleic acids. Br. J. Nutr. 24: 545.

Smith, R. H. \& A. B. McAllan, 1971. Nucleic acid metabolism in the ruminant. Amounts of nucleic acids and total and ammonia nitrogen in digesta from the rumen, duodenum and ileum of calves. Br. J. Nutr. 25: 181 .

Vercoe, J. E., 1969. The transfer of nitrogen from the blood to the rumen in cattle. Aust. J. agric. Res. 20: 191 .

Waldo, D. R., 1968. Symposium 'Nitrogen utilization by the ruminant'. Nitrogen metabolism in the ruminant. J. Dairy Sci. 51: 265.

Walker, D. J., 1965. Energy metabolism and rumen micro-organism. In: R. W. Dougherty (Ed.), Physiology of digestion in the ruminant, p. 296. Butterworth, Washington.

Weller, R. A., F. V. Gray \& A. F. Pilgrim, 1958. The conversion of plant nitrogen to microbial nitrogen in the rumen of the sheep. Br. J. Nutr. 12: 421.

Weston, R. H. \& J. P. Hogan, 1967. The transfer of nitrogen from the blood to the rumen in sheep. Aust. J. biol. Sci. 20: 967. 